\title{
人工リーフ被覆ブロックの初期移動の予測手法 \\ Numerical Prediction of Incipient Motion on Armor Block for Submerged Breakwaters
}

\author{
松本 朗 $^{1}$ - 真野 明 $^{2} \cdot$ 半沢 稔 $^{3} \cdot$ 山本方人 ${ }^{4}$ \\ Akira MATSUMOTO, Akira MANO, Minoru HANZAWA and Masato YAMAMOTO
}

\begin{abstract}
An evaluation method of incipient motion on armor block for submerged breakwater is proposed. The method is based on a wave induced flow field around the submerged breakwater, which is calculated by a numerical wave flume CADMAS-SURF (Isobe et. al., 1999), and successive wave force calculation based on the Morison equation. Trial computation and comparison with experimental results demonstrate the validity and usefulness of the proposed method.
\end{abstract}

\section{1. はじめに}

近年，景観や環境面への配慮から人工リーフの施工事 例が増えている. 人工リーフを被覆するコンクリートブ ロックの所要質量は, 安定定数Ns を用いたハドソン式 (Hudson，1959）により算定するのが一般的である（人 エリーフの設計の手引き，2004）。現在までに，ハドソ ン式をべースとしたブロックの安定性に関する実験的な 検討が数多く実施されてきている（たとえば浅川ら， 1992 ; 中山, 1993 ; 福島ら, 1999 ; 浜口ら, 2007). 八 ドソン式は実用的であり多くの施工事例により実務にお ける妥当性が確認されている. 一方, 精度など問題点も 指摘されている。たとえば, 設計条件が式の適用範囲を 外れる場合には, 個々の設計条件に対応した模型実験に よる検討が必要となるが, 全ての場合について実施する のは費用, 時間の点で困難である。これらを踏まえ, 著 者らは数值計算による流速場を利用して人工リーフの被 覆ブロックの汎用的で精度の高い所要質量算定方法を確 立することを目的として研究を行っている。この設計法 では以下の効果が期待される. (1)人工リーフの形状, あ るいは波の条件の違いを的確に考慮することができる. (2)被覆ブロックの位置による所要質量の違いを表すこと ができる.

被覆材の安定性の議論では被害のばらつきを考慮した 確率的な取扱や被害の進展を考慮することが重要である が, 本論文ではまず被覆ブロックの初期移動の予測手法 を開発することを目的として研究を行った。すなわち, 人工リーフ周辺の流速場を数值計算で求め, その流速場 に基づいて移動の有無を判定する. 流速場の数值計算法

$\begin{array}{lll}1 & \text { 正会員 } & \text { 工修 } \\ 2 & \text { フェロー } \\ 3 & \text { 正会員 } & \text { 工博 } \\ 4 & \text { 工修 }\end{array}$

(株) 不動テトラ総合技術研究所

東北大学教授 災害制御研究センター

(株) 不動テトラブロック環境事業本部

(株) 不動テトラ総合技術研究所
として, 数值波動水路（磯部ら 1999）を用いた. 被覆ブ ロックの波力の算定にはモリソン式を用いた.

\section{2. 水理模型実験}

本研究は, 既報（浜口ら，2007）で示した孔あき被覆 ブロックを例として検討を行った。実験結果は今回の解 析でも用いており，その概要を以下に述べる。詳細につ いては既報を参照されたい.

\section{（1）波力実験}

図-1にブロック設置状況を示す。用いた波浪は周期 $2 \mathrm{~s}$ の規則波である．ブロック天端水深 $R$ は，野口ら（2002） の施工例調査を参考に決定した。調査によれば 9 割の人 工リーフにおいて天端水深 $R$ が $1.0 \mathrm{~m}$ 以上であることか ら，Rを $1.0 \mathrm{~m}$ (模型量で $2.0 \mathrm{~cm})$ とした.

図-2は，天端沖端ブロックおよび法面最上段ブロック に作用する波力のホドグラフである. 水平波力 $F_{\mathrm{x}}$ および 鉛直波力 $F_{\mathrm{z}}$ を $\rho_{w} g H D_{\mathrm{n}}{ }^{2}$ で除した波圧強度で表している. ここで, $\rho_{\mathrm{w}}$ は水の密度, $g$ は重力の加速度, $H$ は波高, $D_{\mathrm{n}}$ は孔あきブロックの体積の 3 乗根である. 実験は孔あ きブロックと孔なしブロックについて行った. 天端沖端 の鉛直波圧強度のピーク值は孔なしブロックの方が大き く, 水平波圧強度のピーク值は孔あきブロックの方が大 きい. 法面最上段においては孔あきブロックおよび孔な しブロックの波力の作用形態に顕著な差異は見られない. いずれも接線方向波力のピーク時には法線方向波力は下

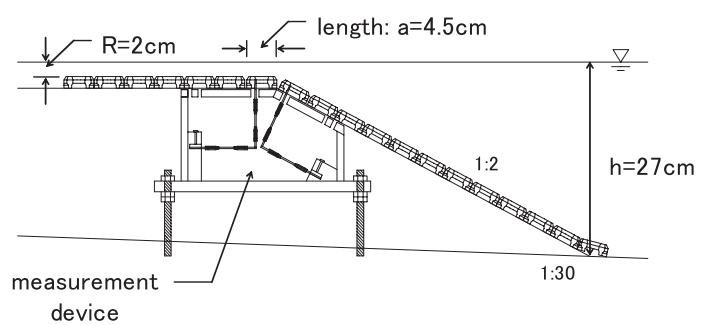

図-1 波力実験装置 

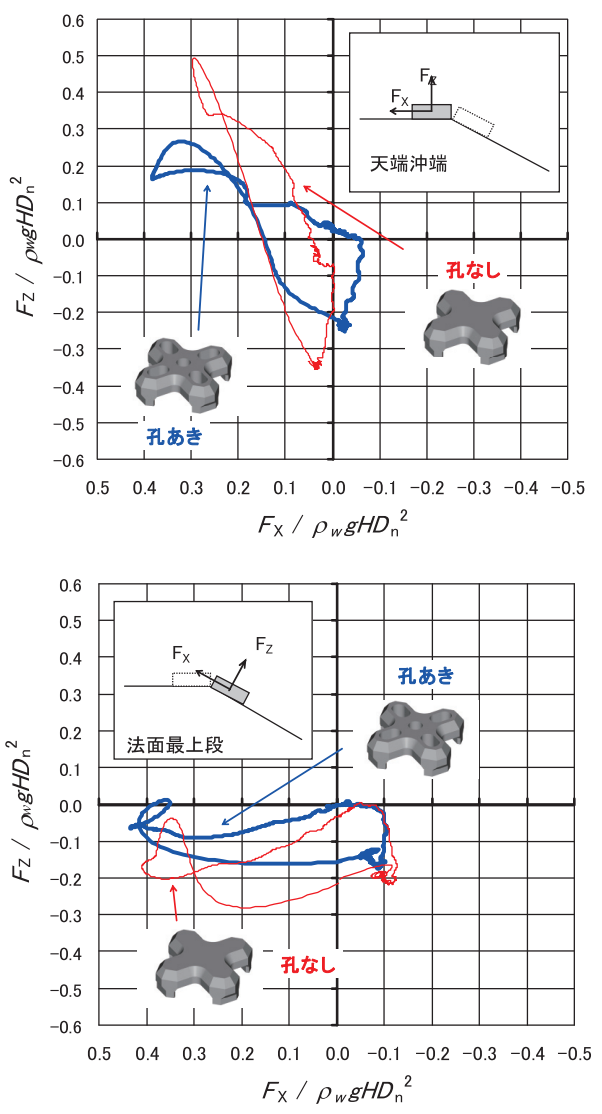

図-2 波力測定結果

(上：天端沖側端部，下：法面最上段）

向きに作用しており，法面最上段ブロックには捨石マウ ンドに押さえつける方向に力が作用することがわかる.

\section{(2) 安定実験}

表-1に実験条件を，図-3に実験断面を示す，有義波周 期 $T_{1 / 3}=1.5,2.0 \mathrm{~s}$ の不規則波を作用させ, ブロックの挙動 を観察した。捨石は人工リーフの設計の手引き（2004） を参考に, 現地量 $10 \sim 500 \mathrm{~kg} /$ 個, 模型量で $0.06 \sim 1.5 \mathrm{~g}$ 個 程度の混合粒径の砕石を用いた。

通常, 人工リーフの被覆に用いられるブロックは, 天

表-1 実験条件

\begin{tabular}{c|c}
\hline 法先水深 $h$ & $25 \mathrm{~cm}$ \\
ブロック天端水樑 $R$ & $0,2,4,6,8,10 \mathrm{~cm}$ \\
マウンド天端幅 $B$ & $100 \mathrm{~cm}$ \\
法面勾配 & $1: 2$ \\
\hline 周波数スペクトル & 修正Bretschneider-光易型スペクトル \\
有義波周期 $T_{1 / 3}$ & $1.5,2.0 \mathrm{~s}$ \\
\hline ブロック模型 & \\
質量 $M$ & $29.3 \mathrm{~g}$ \\
長さ幅 $a$ & $4.5 \mathrm{~cm}$ \\
高さ $D$ & $1.62 \mathrm{~cm}$ \\
密度 $\rho_{\mathrm{r}}$ & $2.3 \mathrm{~g} / \mathrm{cm}^{3}$ \\
\hline
\end{tabular}

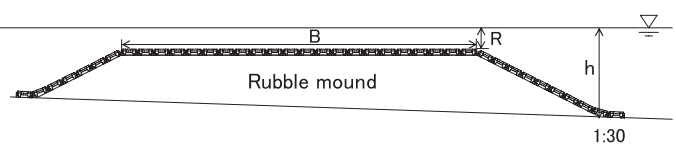

図-3 安定実験断面

端沖側端部のブロックが揚圧力を受け，隣接する岸側の ブロックの沖側上端を中心として岸側へ回転することで 被害が生じることが多い.孔あきブロックの初期被害は, 既存ブロックに扔いて生じる天端沖側端部ではなく，法 面最上段あるいは法面上で生じた。このことは，天端沖 端部に位置する孔あきブロックが揚圧力を効率的に低隇 させていることを示しており，図-2に示した波力の作用 特性に符合する。

\section{3. ブロックの初期移動の予測手法}

\section{（1）基本的考元方}

前章で述べた水理模型実験の結果を踏まえ，予測手法 を構築した．抗力と慣性力に関する簡易な理論によれば, 人工リーフ被覆ブロックでは慣性力の寄与が大きいこと が示される．したがって，流速，加速度の双方を考慮し てモリソン式で作用波力を求め, 自重による抵抗力と比 較してブロックの安定性を判定した。これは，流速のみ を考虑してイスバッシュ数でブロックの安定性を議論す る既往の手法（たとえば大熊ら，2003；近藤ら，2009） と異なる点である。ただし，(1)の効果により揚圧力は 低減されており，初期に被災するのは法面最上段ブロッ クであるため, 揚圧力の効果は考虑していない. (2)被覆 ブロックは群体で設置されるので着目するブロックの抵 抗力には上流側のブロックによる流れの遮蔽効果を考慮 している. (3)沖側法肩部分が構造上の弱点となるため, その位置における抵抗力を周辺部分よりも低減させてい る.これらの流れの遮蔽効果抒よび法肩の形状効果はモ デルパラメータとし, 計算結果と実験結果の比較により その值を定めた。また，(4)被覆ブロックの被害は不規則 波中の最大波 1 波で生じるわけではない。繰返される波 作用によりブロック間の隙間が広がり移動に至る．従っ て本研究では， $1 / 10$ 最大波力に着目して手法を構築した.

\section{（2）作用波力の算定}

ブロックに作用する波力を次のモリソン式で算定する.

$$
F=F_{D}+F_{I}=\frac{1}{2} C_{D} \rho_{w} S u|u|+C_{M} \rho_{w} V \frac{d u}{d t}
$$

ここで, $F_{\mathrm{D}}$ は抗力, $F_{\mathrm{I}}$ は慣性力, $C_{\mathrm{D}}$ と $C_{\mathrm{M}}$ は抗力係数お よび慣性力係数， $S$ と $V$ はブロックの流れ方向の投影面 積と体積, $u$ は流速である. 流速 $u$ は予め数值計算で求め て打り，水平・鉛直方向流速を人工リーフ表面の接線方 向流速に変換して用いている。ここで, 平松・佐藤 
（2010）に倣い, 抗力と慣性力の大きさについて検討す る.簡単のために立方体で考える。波動場を長波で近似 すると抗力の最大值 $F_{\mathrm{Dmax}}$ と慣性力の最大值 $F_{\text {Imax }}$ は以下 のように表せる.

$$
\begin{aligned}
& F_{D \max }=\frac{1}{8} C_{D} \rho_{w} V^{2 / 3} g \frac{H^{2}}{h} \\
& F_{I \max }=C_{M} \rho_{w} V \frac{H \pi}{T} \sqrt{\frac{g}{h}}
\end{aligned}
$$

さらに構造物が砕波帯内に設置されているものとして $H=0.78 h$ とし, また, 抗力係数と慣性力係数の大きさが 同程度であると仮定すると最終的に以下の式を得る。

$$
\frac{F_{D \max }}{F_{\mathrm{I} \max }}=\frac{0.78}{8 \pi} \frac{C_{D}}{C_{M}} \frac{\sqrt{g h} T}{V^{1 / 3}}=\frac{L}{32 D_{n}}
$$

ここで, $h$ は水深， $T$ は周期， $H$ は波高， L は波長である. すなわち, 波長とブロックの代表長さとの比が $32 よ り も$ 小さければ慣性力が卓越することになる。 たとえば人工 リーフの天端上水深 $R=5 \mathrm{~cm}$, 有義波周期 $T_{1 / 3}=2.0 \mathrm{~s}$ の場合, 天端上での波長 $L_{1 / 3}$ は $1.39 \mathrm{~m}$ であり, ブロックの代表長さ を辺長 $0.045 \mathrm{~m}$ とすると $L_{1 / 3} / D_{\mathrm{n}}=31$ となり, 慣性力が卓越 する領域であることがわかる.

\section{4. 実験結果の再現計算}

\section{（1）予測手法のキャリブレーション}

はじめに先に述べた模型実験結果を対象に, パラメー 夕の同定を行った。図-4に流速場の計算領域を示す.人 エリーフの設置水深 $h=25 \mathrm{~cm}$, 天端水深 $R=2,4,7,10 \mathrm{~cm}$ とした. 波浪は不規則波であり, その有義波周期 $T_{1 / 3}$ は $2.0 \mathrm{~s}$ とした。解析には波浪場が定常となった後の $204.8 \mathrm{~s}$ の時系列を使用した。図示していないが，計算領域の左 右両端に長さ $4 \mathrm{~m}$ の吸収帯を設け, 反射波の発生を抑制 している.

図-5に $1 / 10$ 最大波力の空間分布の例を示す.天端上水 深 $R=10 \mathrm{~cm}$ のケースであり，入射有義波高 $H \mathrm{~s}$ が増加する のに従って波力も大きくなるのがわかる. 1/10最大波力 がブロックの自重に基づく滑動抵抗力よりも大きくなる

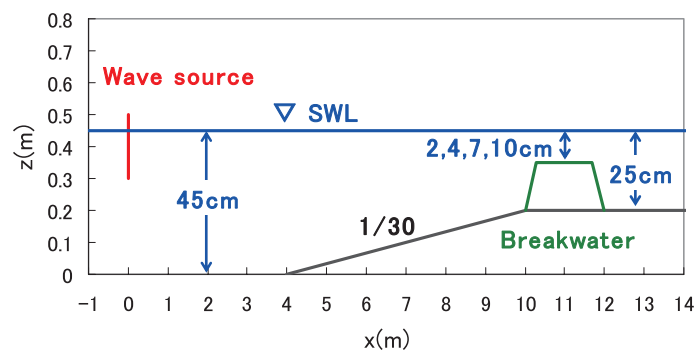

図-4 計算領域
と被災することになる。図-6は滑動抵抗力の設定につい て模式的に表したものである. 滑動抵抗力 $F_{S}$ は以下のよ うに定めた.

$$
F_{S}=\left\{\begin{array}{l}
C_{E} \mu W(\text { 天端 }) \\
C_{R} C_{E} W(\sin \theta+\mu \cos \theta) \text { (斜面) }
\end{array}\right.
$$

ここで, $\theta$ は斜面勾配, $\mu$ は摩擦係数, $W$ はブロックの水 中重量である． $C_{\mathrm{E}}$ は遮蔽効果を表す係数であり 1.0 より も大きい. $C_{\mathrm{R}}$ は斜面上のブロックに対する補正係数であ り, 斜面下部と中間部は 1.0 , 斜面上部は 1.0 未満となる. 試行錯誤の結果， $C_{\mathrm{E}}$ は 4.5 とした. $C_{\mathrm{R}}$ は斜面上段 2 個に ついて 0.3 と設定した.

図-7に算定された $1 / 10$ 最大波力と抵抗力の比率の空間 分布を示す。この值が 1.0 を越えるとブロックが滑動す る. 有義波高が $13.9 \mathrm{~cm}$ と $14.6 \mathrm{~cm}$ の間の条件で被災すると 予測される. 波力と抵抗力の比率は沖側斜面上端で大き な值を取り, 天端で再び極大值を示した後に急激に減少 する，人工リーフの設計の手引きには，天端岸側の被覆 材の質量は沖側よりも小さくできることが示されてお り，その知見と一致している.

図-8に実験と計算による限界安定定数Ns の存在範囲を

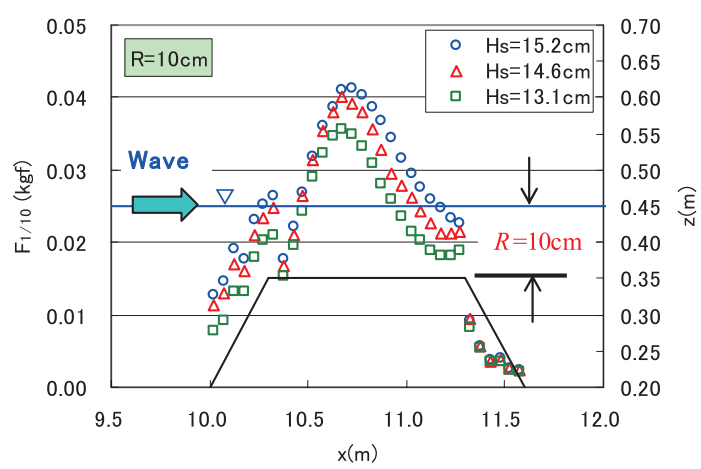

図-5 $1 / 10$ 最大波力の空間分布 $(R=10 \mathrm{~cm})$

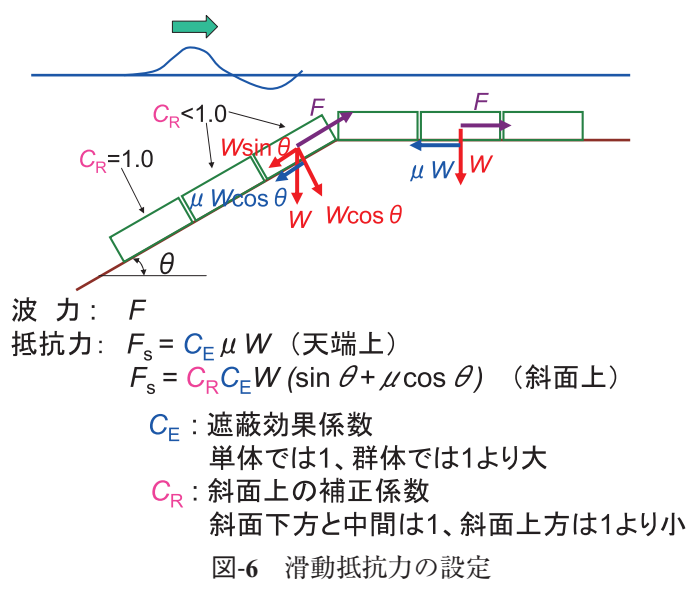


示す. Nsは次式で定義される.

$$
N s=\frac{H_{1 / 3}}{\left(\rho_{r} / \rho_{w}-1\right) D_{n}}
$$

ここで $\rho_{\mathrm{r}}$ はブロックの密度である，被害が生じなかった 最大の安定定数と被害が生じた最小の安定定数を線で結 んで表示している，実験デー夕のばらつきは大きいが, $R / H \mathrm{~s}$ が大きくなるに従って安定定数が大きくなる傾向に ある。計算による限界安定定数は， $R=4,7,10 \mathrm{~cm}$ のケ 一ス $(R / H \mathrm{~s}$ が 0.3 以上) では実験の傾向をよく再現して いるが， $R=2 \mathrm{~cm}$ のケース（ $R / H \mathrm{~s}$ が 0.2 程度）では安定性 が過小評価されている．本モデルは被覆ブロック法線方 向の力を考慮していない．図-2で見たように，接線方向 波力のピーク時には法線方向波力は下向きに作用してお り，安定上有利に作用することになる。このことが $R$ が 小さい条件での実駼結果と計算結果の不一致の原因にな っている可能性があり，詳細な検討は今後行いたい。

\section{(2) 適用性の確認}

前節で同定したパラメー夕を異なる構造条件の人工リ ーフに用いて，手法の適用性を検討した。表-2 はモデル

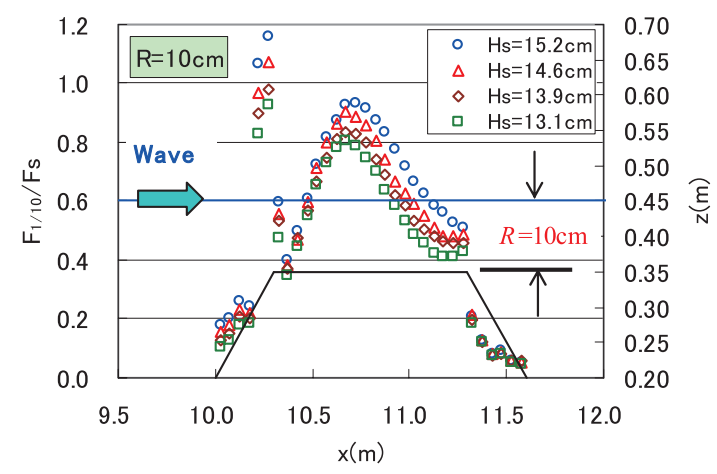

図-7 $1 / 10$ 最大波力と抵抗力の比率の空間分布 $(R=10 \mathrm{~cm})$

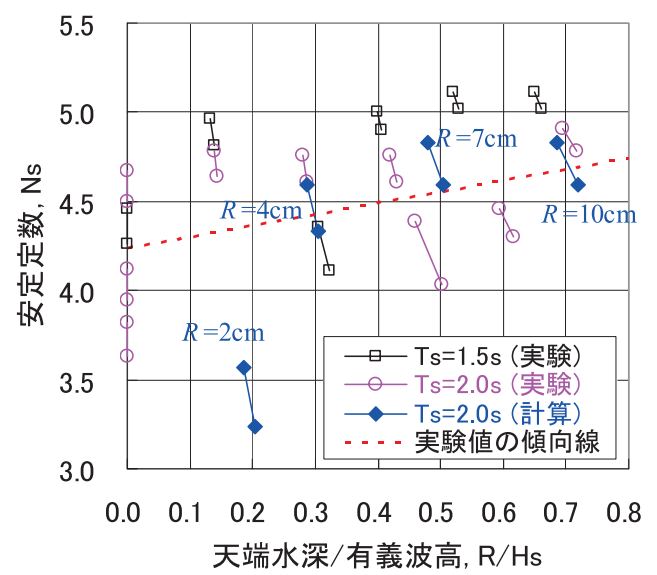

図-8 実験と計算による限界安定定数の存在範囲
の構築と適用性の検討に用いた人工リーフの構造を比較 したものである．適用性の検討に用いた人工リーフ断面 は法面勾配が 1:3 とモデル構築に用いた断面よりも緩勾 配であり，斜面上の流れ場とブロックの滑動抵抗の特性 が変化するものと思われる。

図-9に適用性検討断面における $1 / 10$ 最大波力と抵抗力 の比率の空間分布を示す。計算では，有義波高 $H_{\mathrm{s}}=12.8 \mathrm{~cm}$ の条件で波力と抵抗力の比が $1.00, H_{\mathrm{s}}=13.3 \mathrm{~cm}$ の条件では 1.05 と算定され，ブロックが移動する条件と なった，模型実験においても， $H_{\mathrm{s}}=13.2 \mathrm{~cm}$ の条件で，法 面最上段のブロックが斜面上を岸沖方向に激しく振動す る様子が観察された。最終的には被害に至らなかったが, 安定限界に近い状態であることが確認されており，モデ ルによる予測通りの結果となっている．開発した予測手 法の適用性は高いと言える。

模型実験では，ブロックの質量を増加させた検討も実 施した．図-10は2種類の模型質量に対する波力と抵抗力 の比率の空間分布を示したものであり，ブロックの質量 増加に伴う安定性の向上が定量的に把握できることが本 予測手法の長所である.

表-2 人工リーフ構造の比較

\begin{tabular}{c|c|c}
\hline & モデルの構築 & 適用性の確認 \\
\hline 法先水深 $h$ & $25 \mathrm{~cm}$ & $19.3 \mathrm{~cm}$ \\
ブロック天端水深 $R$ & $4,7,10 \mathrm{~cm}$ & $5.3 \mathrm{~cm}$ \\
法面勾配 & $1: 2$ & $1: 3$ \\
有義波周期 $T_{1 / 3}$ & $2.0 \mathrm{~s}$ & $1.8 \mathrm{~s}$ \\
ブロック質量 $M$ & $29.3 \mathrm{~g}$ & $32.6,64.6 \mathrm{~g}$ \\
\hline
\end{tabular}

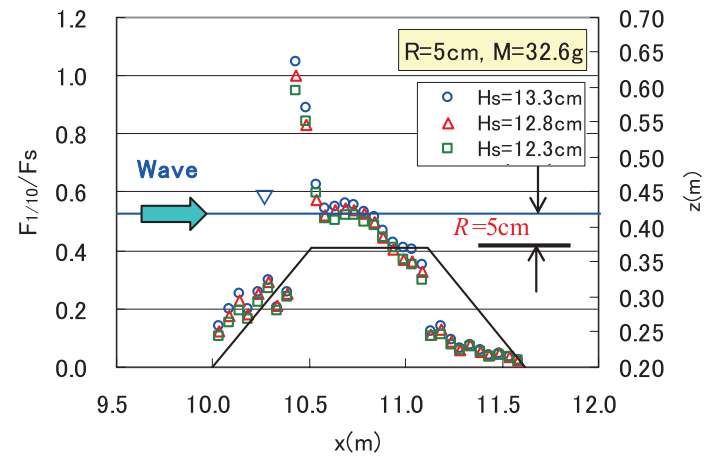

図-9 $1 / 10$ 最大波力と抵抗力の比率の空間分布 $(R=5 \mathrm{~cm}, M=32.6 \mathrm{~g})$

\section{5. むすび}

本研究の結果をまとめると以下のと抢りである.

(1)数值計算による人工リーフ被覆ブロックの初期移動の 予測手法を提案し，実験結果との比較によりモデルに 使用するパラメータの值を定めた。

(2)同定したパラメータを異なる構造条件の人工リーフに 


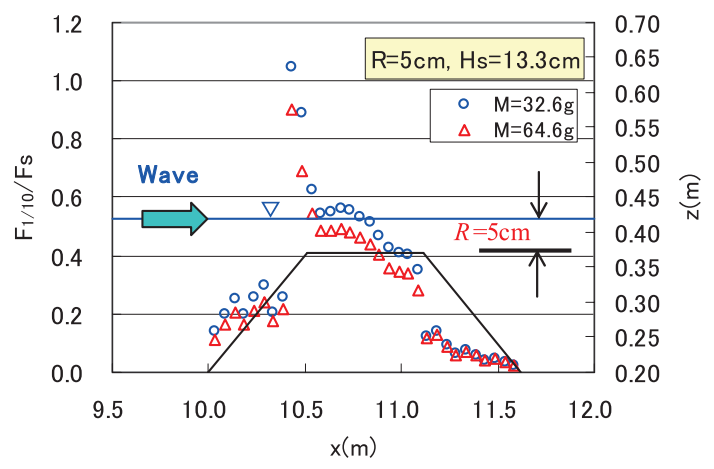

図-10 $1 / 10$ 最大波力と抵抗力の比率の空間分布 $\left(R=5 \mathrm{~cm}, H_{\mathrm{s}}=13.3 \mathrm{~cm}\right)$

用いて, 手法の適用性を検討した. (1)で定めたパラメ ータの值はマウンドの形状が異なる場合にも適用でき ることが確認された。

(3)算定した波力と抵抗力の比率は, 天端上の被覆材の所 要質量の場所的な分布についての既往の知見と一致す るものであった。すなわち，本手法により場所ごとに 異なるブロックの質量を定めることが可能である.

(4)予測された限界安定定数の存在範囲は， $R / H \mathrm{~s}$ が 0.3 以 上では実験結果の傾向をよく再現しているが，R/Hsが 0.2 程度の条件では安定性を過小評価する場合が見られ た。これは，ブロック法線方向の波力をモデルに組み 込むことにより改良できる可能性があるが, 詳細な検 討は今後行いたい.

本論文では予測手法の基本的な考え方を示し，モデル の構築と適用性の確認を行うことに重点が置かれたた め，検討したブロックは1種類である．被覆ブロックの 設計用のNsがブロックの種類ごとに異なる值を取ること からわかるように, 耐波安定性はブロックの形状に依存 するが, 異なる形状のブロックについても, 既存の実験 結果からパラメータのキャリブレーションを行っておけ
ば，マウンドの形状や波浪条件などが異なる場合にも初 期移動を予測することが可能であると思われる.

今後, より多くの設計条件に対して検討を加え, 予 測手法の適用性を確認していく．また，被害のばらつ きを考慮するために, 確率的な取り扱いを付加する予 定である。

\section{参 考 文 献}

浅川 勉・佐藤弘和・ 口ノ町誠・野口正昭 (1992) : 人工リー フ被覆材の安定性に関する実験的研究, 海岸工学論文集, 第39巻, pp.656-660.

磯部雅彦 - 高橋重雄 - 余 錫平 · 榊山 勉 - 藤間功司 · 川崎 浩司・蒋 勤・秋山 実・大山洋志（1999）：数值波動 水路の耐波設計への適用に関する研究 - VOF 法基本プロ グラムの作成 -, 海洋開発論文集, 第 15巻, pp.321-326.

大熊義夫 - 興野俊也 - 柴崎尚史 - 安田勝則 - 中野 修 （2003）：流速場における混成堤断面の被㶤状況の相違に よるブロック安定性検討, 海岸工学論文集, 第 50 巻, pp.751-755.

近藤圭央・有川太郎・関 克己・村川はるみ（2009）：3 次元 数值波動水路を用いた防波堤堤頭部の被覆材移動による 被災の検討, 土木学会論文集 B2 (海岸工学), Vol.65, No.1, pp.861-865.

(社) 全国海岸協会（2004）：人工リーフの設計の手引き（改訂 版), 95p.

中山哲嚴（1993）：人工リーフの水理特性及び被覆材の安定に 関する実験的研究, 海岸工学論文集, 第 40 巻, pp.816820 .

野口賢二・鳥居謙一・人見 寿 ·笛田俊治 - 丸山 準 ・ 岸田 弘之・山崎真嗣（2002）：人工リーフと緩傾斜堤に関する 平成 13 年全国実態調查, 第49回海講論文集, pp.921-925.

浜口正志 - 久保田真一 - 松本 朗 - 半沢 稔 - 山本方人 （2007）：大きな開口部を有する新しい被覆ブロックの開 発と人工リーフへの適用, 海岸工学論文集, 第 54 巻, pp.961-965.

平松遥奈・佐藤愼司 (2010)：サンドパック潜堤の安定性と海 岸侵食緩和機能, 土木学会論文集 B2 (海岸工学), Vol.66, No.1, pp.656-660.

福島雅紀・山本幸次・佐藤愼司・山本吉道（1999）：低天端離 岸堤の被覆ブロック被災機構に関する研究, 海岸工学論 文集,第46巻, pp.896-900.

Hudson, R. Y.(1959): Laboratory investigation of rubble-mound breakwaters, Proc. ASCE, Vol.85, WW3, pp.93-121. 